удК 342.9

DOI https://doi.org/10.32837/apdp.v0i87.2815

М. П. Стрюк

\title{
ДОСВІД США В СИСТЕМІ УПРАВЛІННЯ СЕКТОРОМ БЕЗПЕКИ І ОБОРОНИ
}

Постановка завдання. Сьогодні розвинені демократії зіштовхнулися із рядом фундаментальних викликів. Поруч із загрозами тероризму, війнами значною проблемою постає небезпека поширення нових вірусів на кшталт сучасної коронавірусної пандемії. Водночас Україна лише нещодавно в історичному контексті отримала можливість розбудовувати власну національну державність за зразком передових ліберальних демократій та держав Західного світу. Відповідно, задля того щоб відповідати найкращим західним стандартам в питаннях управління сектором безпеки і оборони, слушним постає фундаментальне вивчення відповідного досвіду та дослідження можливостей його впровадження в Україні із урахуванням місцевих особливостей. Таким чином, зазначена в назві статті проблематика в сучасних умовах має значну актуальність.

Стан опрацювання. Питаннями дослідження іноземного досвіду управління сектором безпеки і оборони, зокрема й відповідним сектором США, займалися та займаються такі зарубіжні та українські дослідники й фахівці в галузі національної безпеки: Н. Городня, Г. Пісковська, А. Рубан, Г. Ситник, Д. Снайдер, Н. Яковенко та інші.

Метою статті $є$ висвітлення особливостей нормативного врегулювання питання управління сектором безпеки і оборони США, характерних рис механізму управління відповідним сектором зі сторони найвищого керівництва США.

Виклад основного матеріалу. Цілком слушним у питаннях висвітлення особливостей управління сектором безпеки розвинених демократій згадати найпотужнішу державу світу, яка будувала сучасні власні інституції та систему управління протягом XX - XXI ст., США. Варто зауважити, що завдання та виклики, які стояли перед США в XX ст. та на початку XXI ст., зазнали суттєвої трансформації. У XX ст. після закінчення Другої світової війни США опинились в так званому біполярному світі, де СРСР загрожував існуванню усієї конструкції Західного ліберального світу, лідером якого виступали якраз США. Після розпаду Радянського союзу та зникнення біполярної системи на перший план серед загроз національній безпеці США вийшли міжнародний тероризм, економічні виклики, швидкі та небезпечні зміни клімату тощо. Наразі за економічне лідерство у світі із США починає серйозно конкурувати КНР, в якому пропагується комуністична ідеологія та існує недемократичний режим.

У дисертаційному дослідження А. Рубан аналізує ті основні принципи, які були сформовані в США після закінчення Другої світової та діяли протягом усієї Холодної війни, тобто періоду протистояння із Радянським союзом. Першим принципом автор називає пріоритетність у процесі формування державної політики й стратегії у сфері забезпечення національної безпеки усунення військових загроз Штатам 
та їхнім союзникам. Другим ключовим принципом постає закріплення принципу залякування та стримування дій супротивника в концептуальних та засадничих документах США, що реалізувалось у розробці найбільш небезпечних, смертоносних та технологічних видів зброї (ядерна зброя масового знищення, побудова авіаносців тощо). Третім виступав принцип переваги під час реалізації політики та стратегії національної безпеки жорстких військових заходів перед політико-дипломатичними та економічними (санкції тощо). Тут варто зауважити, що, на жаль, нинішні світові реалії вказують на низьку ефективність реалізації політики суто дипломатичних, економічних та політичних заходів. Ще одним принципом поставала наявність погоджень у концептуальних документах щодо забезпечення національної безпеки США із захистом їх від зовнішньополітичних та військово-політичних позицій. Під час розробки таких документів влада США використовувала та спиралась у першу чергу на експертну думку фахівців у сфері національної безпеки і оборони, а також зовнішньої політики [3, с. 90].

Коли соціалістичний табір під проводом Радянського союзу та Організацію Варшавського договору було зруйновано, США залишилися єдиною на той час наддержавою, лідером найпотужнішого військового альянсу світу - НАТО, концептуально загроза військової агресії проти США втратила пріоритетність перед економічними, екологічними, терористичними загрозами. На таку зміну ситуації було відредаговано шляхом внесення корективів щодо концептуальних документів у сфері безпеки, а також до підходів щодо реалізації державної політики у відповідній сфері. Це стало проявлятись вже за періоди каденції Дж. Буша-старшого та Б. Клінтона (саме за нього відбулась відмова від норм в доктринальних документах, які були базовими в умовах протистояння із Радянським союзом [3, с. 91].

Разом із тим, не дивлячись на те, що доктринальні документи в питаннях концептуальних підходів щодо національної безпеки зазнавали суттєвих змін в США, варто наголосити, що в США чітко визначені повноваження та процедури взаємодії інституту сектору безпеки, а також роль та місце в системі управління політичної, адміністративної, військової складових частин державного управління національної безпеки визначені законом від 1947 р. «Про національну безпеку», який чинний і на даний момент [4, с. 251].

Загалом, в іноземних державах одними із найважливіших документів загалом сфери забезпечення національної безпеки та, зокрема, в питаннях процесу прийняття рішень та управління займають концептуальні засадничі документи політичного характеру. Здебільшого їх називають у відповідності з національними традиціями та особливостями, однак у цілому згідно з функцією вони типові: в США це Стратегія національної безпеки США, у ФРН це «Біла книга» про безпеку, в Туреччині - «Політичний документ про національну безпеку». У цілому такі документи висвітлюють систему офіційних поглядів на роль відповідної держави у світовому порядку, її національні цінності, завдання, цілі та інтереси, яких вона намагається досягнути та забезпечити зовнішній та внутрішній політиці, разом із тим містить і норми про сили, засоби та способи попередження або знешкодження загроз як ззовні, так і зсередини держави. На основі таких стратегій вибудовується законодавча база, яка вже визначає основи організації 
та принципи функціонування системи забезпечення національної безпеки. Водночас такі стратегічні документи містять положення, які стають орієнтиром для формування та реалізації єдиної загальнодержавної політики у сфері захисту національних інтересів, розробки більш вузьких концепцій та доктрин забезпечення національної безпеки в найважливіших сферах на кшталт військової, міжнародної, економічної, екологічної, інформаційної [2, с. 3-4]. Варто зауважити, що Україні задля ефективної реінтеграції тимчасово окупованих територій Донбасу і тимчасово анексованих територій АР Крим необхідно формувати грунтовну доктринальну та концептуальну систему.

У теорії державного управління національною безпекою існують значні відмінності між поняттями концепцій, стратегій та доктрин у сфері національної безпеки. Г. Ситник вказує, що під поняттям «концепція» розуміється деяка керівна, концептуальна ідея (провідний задум, конструктивний принцип, головна думка). Поняття «доктрина» може бути ідентифіковано як теорія, вчення, що, як відомо, передбачає наукове обґрунтування певної системи принципів, поглядів, настанов. Тобто можна говорити, що в межах доктрини здійснюється подальший розвиток концептуальної ідеї, сформульованої в концепції, який, у кінцевому рахунку, набирає обрисів певної теоретичної конструкції. Поняття «стратегія» асоціюється з такими ключовими словами, як «рішення», «цілі», «мистецтво». Останнє має підкреслити, що процес розробки рішень, які спрямовані на розв’язання тих чи інших проблем (політичних, воєнних та інших), є мистецтвом. Тому метою «стратегії» є деталізація системи поглядів, принципів і настанов, які знайшли своє відображення в «доктрині». Таким чином, у контексті послідовної деталізації та уточнення принципів, підходів, напрямів, цілей, завдань і т.д. щодо розв'язання комплексної проблеми забезпечення національної безпеки має місце ієрархія керівних документів: концепція - доктрина - стратегія» [4, с. 248].

У США щодо формулювання Стратегій національної безпеки (яке відбувається вже десятиліттями) виділяється певна типова структура та елементи у вигляді фундаментальних інтересів (або постійних інтересів), які проявляються у формі забезпечення національної безпеки, процвітання та свободи американського громадянського суспільства; доктрини, яка забезпечує національні інтереси в розумінні конкретного діючого президента США та місія держави, її цілі та завдання у відповідності із сучасними реаліями; визначених цільових установок, які будуть реалізовуватись силами суб'єктів національної безпеки, якими в США можуть поставати президентські адміністрації, державні структури, групи впливу, комерційні та некомерційні організації тощо) [2, с. 4; 6, с. 2-14].

В історичному контексті, до речі, вперше берекову стратегію запропонував Р. Ніксон ще в 1986 р., коли після прийняття закону Голдуотера-Нікольса (внаслідок специфіки двопалатного парламенту в Конгресі закони часто асоціюють за традицією з ініціаторами розгляду законопроекту) передбачалось, що «Стратегія національної безпеки» стала обов'язковим засадничим документом для кожної нової адміністрації президента США (тобто нова повинна з'являтись через кожні чотири роки). Н. Яковенко та Г. Піскорська зазначають, що кожна з таких стратегій базується на принципах абсолютної переваги США у воєнному, технологічному, інфор- 
маційному та економічному плані. Разом із тим серед останніх інструментів передбачена важлива роль невійськових засобів стримування [5, с. 39]. Разом із тим вперше, наприклад, у «Стратегії» адміністрації Б. Обами 2010 р. містилась низка новацій щодо тактичних та стратегічних засад, а саме вперше в системі управління сферою безпеки пропонувалось інтегрувати основні інструменти американської потужності - дипломатію, військову силу, економічні важелі, розвідку, сили забезпечення внутрішньої безпеки. Водночас у даному документі виділялись чотири стратегічні елементи: безпека, економічний розвиток, просування «універсальних цінностей», зміцнення світового порядку в умовах американського домінування у вирішення усіх загальносвітових або регіональних важливих проблем [5, с. 41]. Особливістю системи управління в США сектором безпеки і оборони полягає є те, що в подібних стратегіях передбачалось активний розвиток взаємодії із іншими союзниками за блоком НАТО (ФРН, ВБ, Франція та інші держави).

Національна стратегія 2015 р., запропонована знову адміністрацією Б. Обами, відрізнялась від попередньої. Із цього привозу Н. Городня зазначає, що через усю Стратегію 2015 р. проходить теза про потребу лідерства США у сучасному світі, оскільки лише в цьому разі може бути гарантована їхня безпека, яка не обмежується кордонами держави. У вступі відзначається існування консенсусу серед різних політичних сил США щодо необхідності американського лідерства; питання полягає тільки в тому, як його реалізовувати. Як зазначається, США здійснюють лідерство з позиції сили. Проте «розумна» стратегія національної безпеки не покладається лише на військову силу. Концепція «розумної сили... передбачає вдосконалення, збалансування й інтеграцію усіх силових інструментів: оборони, дипломатії, економіки, допомоги з розвитку, внутрішньої безпеки, розвідки, стратегічних комунікацій, потенціалу американського народу і приватного сектора» [1, с. 5-9]. Разом із тим забезпечення даної Стратегії також передбачалось шляхом залучення широкої коаліції союзних держав задля вирішення міжнародних конфліктів та проблем.

Затверджена Д. Трампом у грудні 2017 р. нова Стратегія національної безпеки передбачала також нові положення та виклики, які стоять перед США. Якщо раніше головними загрозами вважались терористичні організації (які також є серед переліку загроз), тут були зазначені конкретні держави -КНР, Іран, Російська Федерація, Північна Корея [7, с. 25].

Разом із тим, окрім розроблення адміністраціями президентів США Стратегій, президент щорічно повинен звітувати перед Конгресом щодо ії виконання. Такий всебічний звіт подається в день, коли президент подає законопроект про федеральний бюджет на наступний фінансовий рік. Кожен подібний звіт повинен містити ряд важливих елементів, серед яких постають вичерпний опис та обговорення: світових інтересів, цілей та завдань США, які є життєво необхідними для національної безпеки США; зовнішня політика, національні інтереси й обов'язки у світі та національна обороноздатність США, яка передбачає ліквідацію загроз та агресії й допомагає реалізувати стратегію національної безпеки; запропоновані короткострокові та довгострокові плани із використання політичних, економічних, військових та інших елементів федеральної влади США для захисту та просування 
інтересів та досягнення цілей і завдань, які життєво необхідні для національної безпеки США; адекватність можливостей США із реалізації стратегії національної безпеки США, що включає оцінку балансу між можливостями всіх елементів національної влади США для підтримки реалізації стратегії національної безпеки; інші заходи, які можуть бути корисними для інформування Конгресу щодо питань, які стосуються стратегії національної безпеки США [6, с. 1-2]. Такий звіт президент США подає у двох форматах - засекреченому та такому, що може міститись у загальному доступу.

Після рівня Стратегії конкретні завдання усьому сектору безпеки і оборони формулюються в зазначених вже директивах (частково або повністю секретні) вищого органу державної влади, який відповідальний за реалізацію політки у сфері національної безпеки. Потім, спираючись на норми концептуального документа, себто певної доктрини, чітких директив, вже галузеві відомства, які відповідають за реалізацію політики із забезпечення національної безпеки і оборони, окреслюють необхідні до виконання завдання, займаються розподіленням сил та засобів, формують концепції та доктрини в конкретних сферах (військова, економічна, інформаційна, зовнішньополітична).

Конкретні завдання структурам сектору безпеки і оборони країни формулюються у відповідних директивах (які можуть бути повністю або частково секретними) вищого органу, відповідального за реалізацію державної політики у сфері національної безпеки. На підставі проголошеної доктрини (концептуального документа), а також конкретних директив, галузеві відомства, відповідальні за практичну реалізацію політики забезпечення національної безпеки, визначають завдання, розподіляють сили й засоби, розробляють окремі концепції і доктрини у різних сферах (зовнішньополітичній, військовій, економічній, інформаційній та інших). Важливе значення в забезпеченні ефективності процесу прийняття рішень у сфері національної безпеки має закріплений у законодавстві чіткий розподіл відповідальності. Ще одним важливим фактором забезпечення системи управління та прийняття рішень в секторі безпеки і оборони постає в США чітке законодавче розмежування та розподіл відповідальності [2, с. 3-4].

Серед особливостей механізму прийняття управлінських рішень у відповідності до законодавства у сфері безпеки і оборони США виділяють: поєднання в особі президента повноважень голови держави та голови виконавчої гілки влади; в питаннях співіснування сильної президентської влади й Конгресу розгалуженої системи стримувань і противаг; наявність у питаннях прийняття рішень у сфері забезпечення національних інтересів у нормотворчому процесі в руках президента значних повноважень. Акти президента у сфері національної безпеки та оборони оформлюються у вигляді президентських директив (із фактичною силою закону). Директиви можуть стосуватись рішень із надзвичайних ситуацій (наприклад, застосування ядерної зброї у разі відповідного удару по території США), стихійні лиха тощо; рішення, які визначають зовнішньополітичний курс й політику в сфері безпеки; рішення військово-політичного та економічного характеру (розвиток війська тощо); рішення, що стосуються поточних зовнішньо або внутрішньополітичних проблем США [2, с. 5]. 
Висновки. Таким чином, США в питаннях побудови сучасної системи національної безпеки і оборони пройшли тривалий час становлення. Після Другої світової війни засадничі та фундаментальні документи у сфері безпеки й відповідне законодавство реагувало на ті виклики, які постали перед США, разом із тим подібні документи зазнавали трансформації. Після розпаду СРСР головними загрозами перед США поставали терористичні організації. Згодом до головних загроз у таких документах стали визначатись економічні та екологічні проблеми. У стратегії національної безпеки США адміністрації Д. Трампа вперше за тривалий час загрозою стали вважатись конкретні держави: КНР, Іран, Російська Федерація, Північна Корея. Варто наголосити на ефективності механізму прийняття управлінських рішень в США, коли разом із налагодженою системою стримувань і противаг президент США має значні повноваження стрімко реагувати на зовнішні та внутрішні виклики й визначати основні засади зовнішньої політики США.

\section{Jimepamypa}

1. Городня Н. Стратегія національної безпеки США 2015 р.: нові акценти і пріоритети. Вісник Київського університету. Історія. 2014. Вип. 5(123). С. 5- 9.

2. Забезпечення безперервності процесу управління у сфері національної безпеки. Аналітична записка. Наиіональний інститут стратегічних досліджень: веб-сайт. URL : http://old2.niss.gov.ua/ $\operatorname{articles} / 3257 /$ (дата звернення 2.10.2020)

3. Рубан А.В. Державне управління у сфері національної безпеки України : дис. ... канд. держ. упр. : 25.00.05 / Національний університет цивільного захисту України, Харків, 2019. 253 с.

4. Ситник Г.П. Державне управління у сфері національної безпеки (концептуальні та організаційно-правові засади) : підручник Київ : НАДУ, 2012. 544 с.

5. Яковенко Н., Піскорська Г. Пріоритети міжнародно-політичної діяльності США в стратегіях національної безпеки. Американська історія та політика. 2016. № 2. С. 38-47.

6. Snider D.S., The National Security Strategy: Documenting Strategic Vision. Strategic Studies Institute, U.S. Army War College. Carlisle Barracks, March 15, 1995. p. 21 p.

7. The National Security Strategy of the United States of America. Whitehouse.gov: веб-сайт. 68 p. URL : https://www.whitehouse.gov/wp-content/uploads/2017/12/NSS-Final-12-18-2017-0905.pdf (дата звернення: 5.10.2020).

\section{Анотація}

Стрюк М. П. Досвід СШІА в системі управління сектором безпеки і оборони. - Стаття.

$\mathrm{y}$ статті йдеться про нормативні засади й доктринальні документи, які визначають основні пріоритети та принципи, що використовуються під час реалізації зовнішньої та внутрішньої політики Сполученими Штатами Америки у сфері національної безпеки і оборони. Зазначаються принципи, які сформулювались в США під час Холодної війни з Радянським союзом (пріоритет усунення військових загроз США та союзників, принцип стримування та залякування супротивників США в засадничих документах, принцип переваги жорстких дій у вирішення конфліктів, які можуть загрожувати національній безпеці США). Акцентовано увагу, що після розпаду Радянського союзу загроза повномасштабної військової агресії проти США постає в документах на другий план, а на перший виходять тероризм, економічні та екологічні проблеми. Наголошується, що в США, окрім доктринальних та концептуальних документів, щодо сектору безпеки і оборони діє закон 1947 p. «Про національну безпеку", який чітко визначає процедурні аспекти взаємодії та повноваження усього інституту сектору безпеки і оборони. Вказуються основні відмінності та зміст понять "концепція», "доктрина», «стратегія» в теорії державного управління сектором безпеки і оборони. Наголошується, що в США існують загальні елементи та закономірності щодо цілей Стратегії національної безпеки у вигляді фундаментальних інтересів США: забезпечення національної безпеки, процвітання та свободи американських громадян, доктрини про національні інтереси в розумінні кожного президента, визначення цілей та завдань, місця США у світовому порядку, визначення завдань, які будуть реалізовуватись суб'єктами сектору національної безпеки та оборони США. Наводяться в дослідженні відмінності 
щодо основних засад стратегій національної безпеки від адміністрацій Б. Обами 2010 р. та 2015 р., а також Д. Трампа 2017 р. Наводяться особливості механізму прийняття управлінських рішень у відповідності до законодавства у сфері безпеки і оборони США.

Ключові слова: Стратегія національної безпеки, доктрина, концепція, США, адміністрація президента, терористична загроза.

\section{Summary}

Striuk M.P. US experience in security and defense management system. - Article.

The article discusses the normative principles and doctrinal documents that define the main priorities and principles used in the implementation of foreign and domestic policy of the United States in the field of national security and defense. The principles formulated in the United States during the Cold War with the Soviet Union (priority to eliminate US military threats and allies, the principle of deterrence and intimidation of US opponents in the basic documents, the principle of priority of tough action in resolving conflicts that may threaten US national security). It is emphasized that after the collapse of the Soviet Union, the threat of full-scale military aggression against the United States appears in the background, and terrorism, economic and environmental issues come to the fore. It is noted that in the United States, in addition to doctrinal and conceptual documents on the security and defense sector, there is a law of 1947 "On National Security", which clearly defines the procedural aspects of interaction and powers of the entire institution of the security and defense sector. The main differences and content of the concepts "concept", "doctrine", "strategy" in the theory of public administration of the security and defense sector are indicated. It is emphasized that in the United States there are common elements and patterns regarding the goals of the National Security Strategy in the form of fundamental US interests: ensuring national security, prosperity and freedom of American citizens, doctrines of national interests in understanding each president, defining goals and objectives, defining the tasks that will be implemented by the subjects of the US national security and defense sector. The study presents differences in the basic principles of national security strategies from the B. Obama administrations in 2010 and 2015, as well as D. Trump in 2017. The features of the mechanism for making management decisions in accordance with US security and defense legislation.

Key words: National security strategy, doctrine, concept, USA, presidential administration, terrorist threat. 